\title{
Oyster Mushroom (Pleurotus ostreatus) Inhibits Migration and Metastasis on 4TI Breast Cancer Cells
}

\author{
Lodyta Nawang Tika, Layung Sekar Sih Wikanthi, Shofa Annur, \\ Retno Murwanti*
}

Faculty of Pharmacy, Universitas Gadjah Mada

\begin{abstract}
Metastasis is the main cause of death among brast cancer patient. Pleorotus ostreatus is known as anticancer agent that inhibits angiogenesis. Ethanolic extract of Pleorotus ostreatus (EEP) which contains lovastatin is predicted to inhibit metastatic cancer through inhibition of MMP-2 and MMP-9. The aim of this study was to determined antiproliferative and anti metastatic activity of EEPw (Ethanolic extract of wet Pleorotus ostreatus) and EEPd (Ethanolic extract of dried Pleorotus ostreatus) in 4TI metastatic breast cancer cells line. Qualitative analysis of lovastatin was determined by thin layer chromatography (TLC) using dicloromethan and etil acetat as mobile phase and lovastatin standard. Scratch wound healing assay was used to determine migration inhition ability of EEP while MMP-9 and MMP-2 activity were analysed by gelatine zymography. Molecular docking was performed to know the interaction between lovastatin and MMP-2 \& MMP-9. The result showed that EEPw and EEPd contain lovastatin which were proved by spray reaction with anisaldehid. Each of EEPw and EPPd had cytotoxic activity with $\mathrm{IC}_{50} 760$ and $400 \mu \mathrm{g} / \mathrm{mL}$ respectively. Both of them inhibited closure for about $50 \%$ on $4 \mathrm{TI}$ metastatic breast cancer cells line compared to control. Either EEPw or EEPd decreased MMP-9 expression level compared to control. Lovastatin had higher affinity to bond with either MMP-2 or MMP-9 than native ligand. Overall, EEP could be developed as anticancer agent which was targeted on MMP-2 and MMP-9.
\end{abstract}

Keywords : Pleurotus ostreatus, 4TI metastatic cells, MMP-2, MMP-2, antimetastatic

\section{INTRODUCTION}

In 2014, $21.4 \%$ of deaths among women was due to breast cancer (WHO, 2014), especially after the occurrence of metastasis. Metastasis is a complex molecular process which cancer cells leave the first place to grow towards other organs and proliferate to form a new tumor mass (Brooks, et al., 2010). Metastasis activity was due to the activity of metalloproteinases (MMPs), especially MMP-2 and MMP-9 which degraded collagenase VI (gelatin) in cancer cells (Liotta, 1991, StetlerStevenson, 1994). Nowdays, treatment of metastatic cancer is targeted to the activity of MMP-2 and MMP-9. Effective and efficient treatment can be done by utilizing potential compounds from natural materials such as oyster mushroom (Pleurotus ostreatus).

P.ostreatus is an edible mushroom that contains lovastatin (Lakshmanan and Radha, 2013). Lovastatin could decreased angiogenesis by inhibit VEGF activity (Zhao, et al., 2010;
Xiao, et al., 2012). Angiogenesis triggered cancer cell metastasis (Rivilis, et al., 2002). Therefore, lovastatin activity as inhibitors of VEGF could inhibit MMP-2 and MMP-9 activity to prevent metastasis.

This study aims to determined the ability of P.ostreatus extract to inhibit cancer cells proliferation and metastasis. The study was conducted by observing cell migration by scratch wound healing assay and protein activity of MMP-2 and MMP-9 by gelatin zymography. At the molecular level, molecular docking was performed between lovastatin and target protein MMP-2 and MMP-9.

$\overline{\text { *Corresponding author e-mail : retno_murwanti@ugm.ac.id }}$ 


\section{MATERIALS AND METHODS}

\section{Sample}

The P.ostreatus were collected from Sleman, Yogyakarta and determined by Biological Pharmacy Labroratorium, Faculty of Pharmacy Universitas Gadjah Mada. P.ostreatus were extracted in ethanol $96 \%$ for $72 \mathrm{~h}$, then the mixture was filtered to remove the marc. The extract was concentrated using rotary evaporator. Sample was dissolved in dimethyl Sulfoxide (DMSO) (Sigma). Both of EEPd and EEPw were diluted in cell culture medium before being applied. DMSO was used as the co-solvent to dissolved samples in culture medium.

\section{Cell Culture}

4T1 cells were obtained from Cancer Cancer Chemoprevention Research Center, Yogyakarta. The cells were maintained in DMEM (Gibco) supplemented with $10 \%$ Fetal Bovine Serum (FBS) (Sigma), 1.5\% PenicillinStreptomycin, and $0.5 \%$ fungizone at $37^{\circ} \mathrm{C}$ in humidified atmosphere of $5 \% \mathrm{CO}_{2}$. TrypsinEDTA $0.25 \%$ (Gibco) was used in cell subculture.

\section{Cell Viability Assay}

Cell viability was determined using MTT assay. Cells were seeded into a 96-well plate (8000 cells per well) and incubated for $24 \mathrm{~h}$. Cells were treated with various concentration of EEPd and EEPw. Certain concentration of either single or combination of samples were the applied. After $48 \mathrm{~h}$ incubation, MTT reagent [3-(4,5-dimethyl-2.thiazolyl)-2,5-

diphenyltetrazolium bromide in PBS $(5 \mathrm{mg} / \mathrm{mL})]$ was added to each well. The plate was incubated in a humidified atmosphere of $5 \% \mathrm{CO}_{2}$ at $37^{\circ} \mathrm{C}$ for $3 \mathrm{~h}$, formazan crystals were dissolved in $10 \%$ SDS and incubated overnight. The absorbance of cells was measured at 595 $\mathrm{nm}$ by a microplate reader. The data was presented as percentage of viable cells (\%).

\section{Scratch Wound Healing Assay}

Cells $\left(5 \times 10^{4}\right.$ cells/well $)$ were seeded on 24 well plates until $80 \%$ confluent. Cells were scartched using microtip. Cells were incubated $24 \mathrm{~h}$ hour, then replaced with fresh medium contain EEPw and EEPd. After that incubated in $37^{\circ} \mathrm{C}$ for $48 \mathrm{~h}$, cells were observed in $0 \mathrm{~h}, 18$ $\mathrm{h}, 24 \mathrm{~h}$, and $42 \mathrm{~h}$ under the microscope.

\section{Gelatin-Zymograph Methods}

Gel of $20 \%$ acrylamid-bis acrylamid containing $1 \%$ gelatin was made in the buffer. Cells were washed by PBS and then incubated in $37^{\circ} \mathrm{C}$ for $24 \mathrm{~h}$. Medium was collected and centrifuged at $400 \mathrm{~g}$ for $5 \mathrm{~min}, 4^{\circ} \mathrm{C}$ and supernatant was collected. Cells were washed with cold PBS then added with $2 \mathrm{ml}$ cold lysis buffer.

Cells was harvested with a scrapper to collect lysate and incubated on ice for 15 minutes. Lysate then centrifuged for $16000 \mathrm{~g}$ for $2 \mathrm{~min}$ at $4^{\circ} \mathrm{C}$ and supernatant was collected. Mix $75 \mathrm{~mL}$ of the supernatant with $25 \mathrm{~mL}$ of sample buffer $(4 \mathrm{x}) .30 \mathrm{~mL}$ of sample was put into sinks. Electrophoresis was performed with the condition of $125 \mathrm{~V}, 30-40 \mathrm{~mA}$ for 90 minutes. The Gel then soaked in coomasie blue dye solution for 1 hour to form a transparent band with a dark blue background.

\section{Molecular Docking}

In silico study by molecular docking was conducted to examine the affinity of ligand to its docking site by evaluating drug-receptor binding energy. Evaluation of the interaction between a molecule and its docking protein involved in particular signal transduction may represent its potential biological activity and allow us to determine the possible mechanism of action. In this study, the docking of lovastatin in Ligan native. Ligand preparation was done by using Marvin Sketch. Protein preparation was done by using YASARA. Molecular docking was conducted by using PLANTS (Protein-Ligand Ant System) Software, giving $\Delta \mathrm{G}$ as docking score result.

\section{RESULTS}

\section{EEPw and EEPd Showed Cytotoxic Activity on 4TI Cells \\ Cell viability assay was done to} determine the inhibitory concentration $\left(\mathrm{IC}_{50}\right)$ of EEPw and EEPd, on 4T1cells (Fig. 1). All of these compounds shows cytotoxic effect in dose dependent manner. EEPw and EEPd had the $\mathrm{IC}_{50}$ values of $760 \mu \mathrm{g} / \mathrm{mL}$ and $400 \mu \mathrm{g} / \mathrm{mL}$, respectively. 


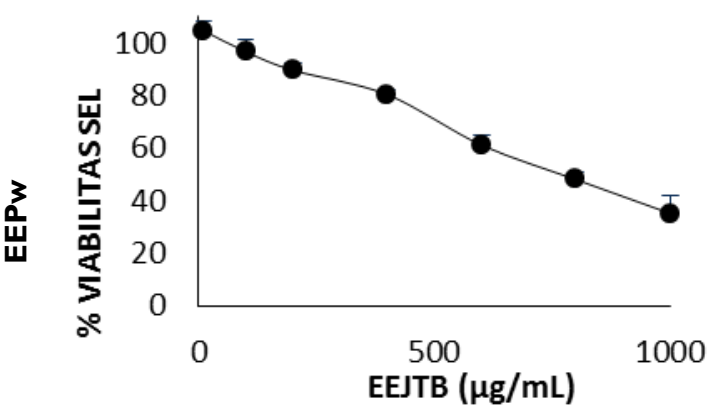

$\operatorname{EEPw}(\mu \mathrm{g} / \mathrm{mL})$

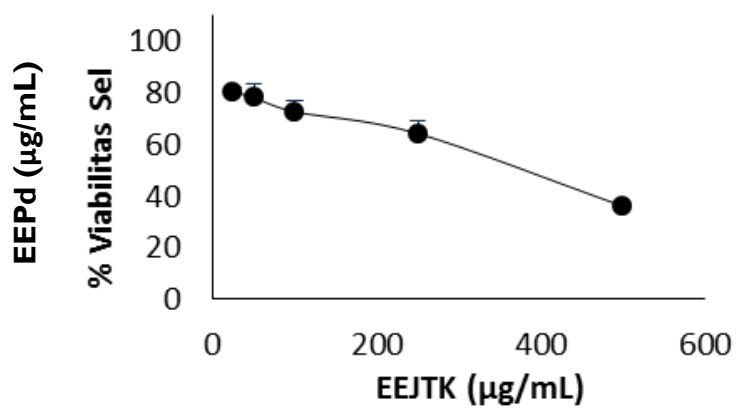

$\operatorname{EEPd}(\mu \mathrm{g} / \mathrm{mL})$

Figure I. Cell viability assay of (a) EEPw (b) EEPd in 4TI cells. Cells were incubated for $24 \mathrm{~h}$ then add with MTT and incubated overnight then read the absorbance using ELISA reader. Result showed that EEPd and EEPw had the $\mathrm{IC}_{50}$ values $400 \mu \mathrm{g} / \mathrm{mL}$ (a) and $760 \mu \mathrm{g} / \mathrm{mL}$ (b).

\section{Scratch Wound Healing Assay}

The scratch assay was done to explored EEPw and EEPd effect in migration breast cancer cell 4T1 (Fig.2 and 3). 4T1 cell was used as model in scratch assay due to its ability to performed metastasis.

EEPw and EEPd had the abilit to lowering the closure area on 4T1 breast metastatic cells compared to control cells.

\section{Molecular docking}

In silico test by molecular docking was done to predict the ability of oleandrin and synamaldehid to interacting with MMP-2 and MMP-9 receptor. That interaction is visualized and determinated by amino acid residue which interacting between oleandrin and cynamaldehid ligand against MMP-2 and MMP-9 (Table 1).
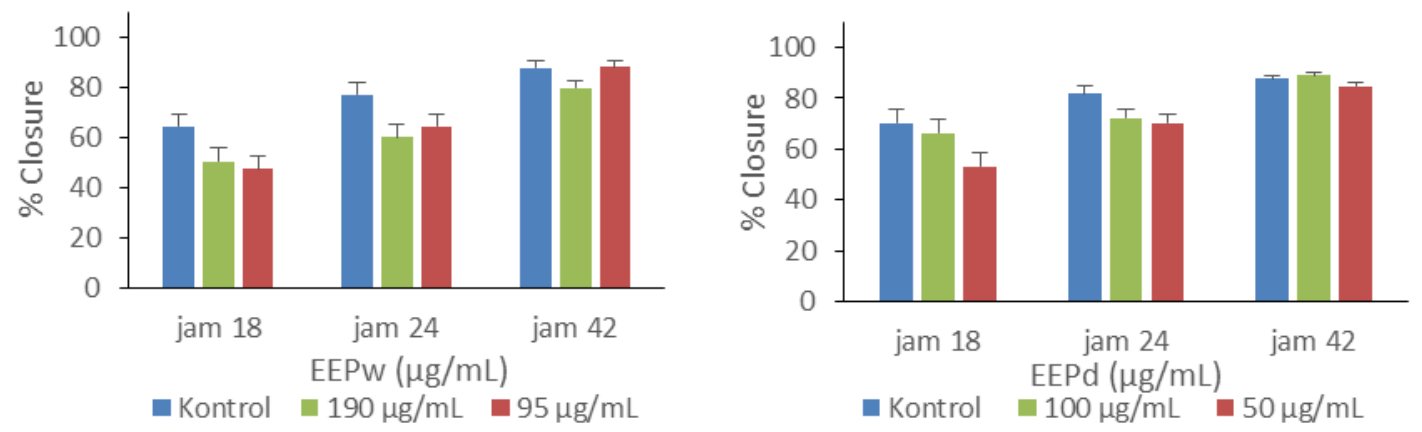

Figure 2. Effect of EEPd and EEPw against \% closure. Observation area closure was performed using Image-J program to calculate the area of a scratch on $0 \mathrm{~h}, 18 \mathrm{~h}, 24 \mathrm{~h}$ and $42 \mathrm{~h}$ with a concentration EEPw or EEPd $1 / 4$ and $1 / 8$ then expressed as $\%$ closure.

\section{Gelatin Zymograph assay}

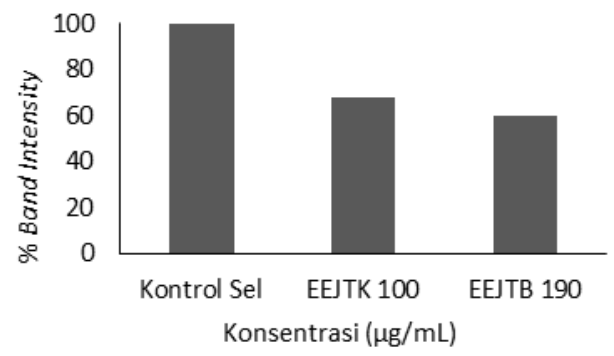

Figure 3. Effect EEPw and EEPd to \% the intensity of the band 
Table I. Molecular Docking Score

\begin{tabular}{llc}
\hline & MMP-2 & MMP-9 \\
\hline RMSD & $2,375^{\circ} \mathrm{A}$ & $\mathrm{I}, 8338^{\circ} \mathrm{A}$ \\
Lovastatin & $-11 \mathrm{I}$ & -94 \\
Ligan Native & -124 & -136 \\
\hline
\end{tabular}

\section{DISCUSSION}

Overexpression of the protein MMP-2 and MMP-9 is one factor leading to breast cancer cell metastasis (Liotta, 1991). The results showed that EEPw and EEPd were cytotoxic against 4T1 breast cancer cells with $\mathrm{IC}_{50}$ of $760 \mu \mathrm{g} / \mathrm{mL}$ and $400 \mu \mathrm{g} / \mathrm{mL}$ respectively. EEP has intermediate potency as cytotoxic agent.

Inhibition of the closure area show the ability of EEP to reduce breast cancer cell migration. Results of the study showed that EEPw and EEPd with the smallest concentration of IC50 could of decreased \% closures compared to control cells.

MMP-9 is an MMP family members that have been known to have a role in the invasion and metastasis of cancer cells. MMP-9 are classified into type IV collagenase is based on its ability to hydrolyze IV collagen (gelatine) (Wilhelm, et al., 1989). Results of the test using the gelatin zymograph showed a decrease in activity of MMP-9. EEPd and EEPw reduce the expression of MMP-9 protein in compare to control based on the intensity of the band.

Based on molecular docking, lovastatin could to compete with native ligand to interact with MMP-2 and MMP-9 as being shown through the same amino acid residue that interacted with protein MMP-2 and MMP-9. Therefore, bond between lovastatin with MMP2 and MMP-9 can reduce the chances of continuous proliferation through inhibition of protein expression of MMP-2 and MMP-9. These results indicate that EEP inhibit expression of MMP-2 and MMP-9 protein. Hence, proliferation of 4T1 breast cancer cells could be inhibited.

\section{CONCLUSION}

The results showed that EEP reduce viability of $4 \mathrm{~T} 1$ breast cancer cells and inhibits cell migration and protein expression of MMP2 and MMP-9.

\section{REFERENCES}

Alarcón,J., Aguila, S., Arancibia-Avila, P., Fuentes, O., Zamorano-Ponce, E. and Hernández M., 2002, Production and Purification of Statins from Pleurotus ostreatus (Basidiomycetes) Strains., Z. Naturforsch C., 58(I-2),62-4.

Brooks, S.A, Lomax-Browne, H.J., Carter, T.M., Kinch, C.E. and Hall, D.M., 2010, Molecular Interaction in Cancer Cell Metastasis, Acta Histochem., I I 2(I), 325.

Green, M. and Riana, V., 2008, Epidemiology Screening and Diagnosis of Breast Cancer in the Asia-Pasific Region: Current Perspectives and Important Consideration, Asia Pac. J. Clin. Oncol., 4(S3),S5-SI3.

Herndndez, D., Sanchez, J.E. and Yamasaki, K., 2003, A Simple Procedure for Preparing Substrate for P. Ostreatus Cultivation, Bioresour. Technol., 90(2), I45-I50.

Kalmis, E., Azbar, N., Yildiz, H. and Kalyoncu, F., 2008, Feasibility of Using Olive Mill Effluent (OME) as a Wetting Agent During the Cultivation of Oyster Mushroom, Pleurotus ostreatus on Wheat Straw, Bioresour. Technol., 99(I), I64-169.

Lakshmanan, D. and Radha, K.V., 2012, Production of Lovastatin from Pleurotus ostreatus and Comparison with Commercial Tablets, Int. J. Pharm. Pharm. Sci., 2(3), 53-56.

Liotta, L.A., Steeg, P.S. and Stetler-Stevenson, W.G., I99I, Cancer Metastasis and Angiogenesis: an Imbalance of Possitive and Negative Regulation, Cell, 64(2), 327-336.

Ramirez, A., Clavijo, C., Palanisamy, M., SolerRivas, C., Rodriguez, A., Francisco, M.M., et al., 2011, Edible Mushrooms as Potensial Sources of New Hypocholesterolemic Compound, 
International Conference on Mushroom Biology and Mushroom Products.

Ramírez-Anguiano, A.C., Santoyo, S., Reglero, G. and Soler-Rivas, C., 2007, Radical Scavenging Activities, Endogenous Oxidative Enzymes and Total Phenols in Edible Mushrooms Commonly Consumed in Europe, J. Sci. Food Agric., 87( I 2), 2272-2278.

Rivilis, I., Milkiewicz, M., Boyd, P., Goldstein, J., Brown, M.D., Egginton, S., et al., 2002, Differential Involvement of MMP-2 and VEGF During Muscle Stretch - versus Shear Stress-induced Angiogenesis, Am. J. Physiol. Heart Circ. Physiol., 283(4), $\mathrm{HI} 430-\mathrm{HI} 438$.

Stelter-Stevenson, W.G., 1994, Progegelatinase A Activation During Tumour Cell Invasion, Invasion Metastasis, I4(I-6), 259-268.

Toth M, Fridman R. 20II. Assessment of gelatinases (MMP-2 and MMP-9) by Gelatin Zymography, Methods Mol. Med., 57, 163-174.

WHO, 2014, WHO | Cancer' WHO, https://www.who.int/mediacentre/factsh eets/fs297/en/, Cited August, 19, 2014.

Wilhelm, S.M., Collier, I.E., Marmer, B.L., Eisen, A.Z., Grant, G.A. and Goldberg, G.I., 1989, SV40-Transformed Human Lung
Fibroblasts Secrete a $92-\mathrm{kDa}$ type IV Collagenase Which is Idential to That Secreted by Normal Human Macrophage, J. Biol. Chem., 264(29), I7213-I7321.

Wong, W.W., Dimitroulakos, J., Minden, M.D. and Penn, L.Z., 2002, HMG-CoA Reductase Inhibitors and The Malignant Cell: the Statin Family of Drugs as Triggers of Tumor-Specific Apoptosis, Leukemia, I6(4), 508-519.

Wu, J., Wong, W.W., Khosravi, F., Minden, M.D. and Penn, L.Z., 2004, Blocking the Raf/MEK/ERK Pathway Sensitizes Acute Myelogenous Leukemia Cells to Lovastatin-induced Apoptosis, Cancer Res., 64(I8),646I-6468.

Xiao, Y., Li, Y., Han, J., Pan, Y., Tie, L. and Li, X., 2012, Transgelin 2 Participates in Lovastatin-Induced- Anti-angiogenic Effectc in Endhothelial Through a Phorphorylated Myosin Light ChainRelated Mechanism, PloS One, 7(10), e465I0.

Zhao, T.T., Trinh, D., Addison, C.L. and Dimitroulako, J., 2010, Lovastatin Inhibits VEGFR and AKT Synergisitic Cytotoxity in Combination with VEGFR Inhibitor, PloS One, 5(9), el 2563. 